\title{
CORPORATE GOVERNANCE AND BANK PERFORMANCE IN NIGERIA: AN EMPIRICAL INVESTIGATION
}

\author{
Jude Jisike Okonkwo \\ Nnamdi Azikiwe University, Awka
}

$\boldsymbol{\&}$

Bernard Chukwuebuka Azolibe

Nnamdi Azikiwe University, Awka

\begin{abstract}
The prevalent issue of manipulation and abuse among Nigerian banks necessitated this study. Thus, this research study extensively the effectiveness of corporate governance in Nigerian banks for the period 2006-2018. The study adopted secondary time series data obtained from annual reports of banks, publications of the Central Bank of Nigeria and Nigeria Stock Exchange annual reports and factbook. A diagnostic test was conducted to ensure that the models are in line with basic econometric assumptions. The granger causality test was applied to examine the effect of the independent variable on the dependent variable. The findings show that corporate governance has a significant effect on performance. It recommends an optimum proportion of outside directors for effective governance impacting performance positively.
\end{abstract}

Keywords: Corporate governance, effectiveness, performance, Nigerian banks

\section{Introduction}

Since banks are important institutions for growth, it is crucial to understand the key integrant for maximizing performance and their role in growing an economy. Abobakr (2017) opined that bank governance became a subject of empirical studies only recently, especially after the occurrence of the recent financial crisis. The banking industry globally has witnessed a lot of reforms over a period of time ranging from size, audit committee, board composition, block shareholding, operations and processes. With the attendant concentration at which these changes in the banking industry occur, there is a need to brace up for the challenges by the banks especially in the aspect of beefing up its corporate governance environment. Poor corporate governance may contribute to bank failure which can pose significant public cost and consequences (Rahman and Islam 2018; Hajer and Anis 2016; Onofrei, Firtescu, and Terinte, 2018).

Several studies by authors like (Egungwu and Egunwu, 2018; Adigwe, Nwanna and John, 2016; Ugwuanyi and Amanze, 2014) who in their consensus views concluded that the failure of banks in Nigeria and elsewhere has been largely due to merely inadequate corporate governance and failure of professional ethics. This is manifested in numerous instances of creative accounting practices, professional insensitive internal control and risk management position been seriously compromised even to the point of colluding with fraudsters. Non-adherence to corporate governance was identified as one of the critical issues in virtually all known instances of financial distress in the past. It also led/ to the development of the 13point agenda which was introduced in 2004 by the Central Bank administration in Nigeria to promote a different set of corporate governance in that era. Tijjani and Anifowose (2013) suggest that the poor performance of boards in 2009 which almost led to the near-collapse of 
nine banks including the collapse of Oceanic and Intercontinental banks has eroded investors' confidence in banks leading them into divesting their investments and has painted a poor image on the financial sector.

Corporate governance in the banking industry provides the platform that is used to attract investors both local and foreign with the trust that their investment will be safe and properly utilized in the best possible means of managing an investment (Fanta, Kemai and Waka, 2013; Mohammed and Farouk, 2014; Abdulazeez, Ndibe and Mercy, 2016). Dharmastuti and Wahyudi (2013) suggested that in an organization, especially a public corporation, functional specialization is required to achieve more efficient goals. Thus an efficient governance structure must be effective in the alleviation of such a giant problem (the agency problem) and ultimately resulting in a better performance (Naushadi and Malik, 2015). Shareholders on their part demand high proficiency on the part of managers with the ultimate aim of delivering high returns given the inclement investment climate because certain factors influence shareholder value more than others including among others are impacted firm value and stock returns (Zadollah and Mohsen, 2015; Adekunle and Aghedo, 2014).

There have been conflicting views on the result of different studies done on corporate governance and bank performance. Some studies were done, in Nigeria, which include Muhammad and Fayrouk (2014), Onakoya, Ofoegu and Fasanya (2012), etc. The studies discovered a positive relationship between corporate governance and bank performance. While some other studies which were carried out in Pakistan by Marcinkowska (2012) in Poland, Reskino (2013) in Indonesia indicate a negative relationship between corporate governance and bank performance with similar time series characteristic of data. Kumar and Singh (2012) established that corporate governance has a significant effect on bank performance in India. Authors like Love and Rachinsky (2013) and Naushadi and Malik (2015) in Russia and Canada respectively discovered that studies have failed to establish a link between the standard in corporate governance and performance.

\section{Literature review}

Corporate governance for banks may be described as the way the activities and business of the banks are conducted and governed by the management team and board. Basically, corporate governance in the nation's banking system provides the structure and processes within which the business of a bank is conducted with the ultimate objective of realizing long term shareholders value while taking into account the interest of all other legitimate stakeholders (Uwuigbe 2013). This study is anchored on Agency Theory. In Agency Theory, Berle and Means (1962) noted that with the separation of ownership and control, and the wide dispersion of ownership, there was effectively no check upon the executive autonomy of corporate managers. This theory as it relates to corporate governance suggests a fundamental problem for absent or distant owners/shareholders who employ professional executives to act on their behalf. This raises the prospect that the executive, as an agent, will serve their own interests rather than those of the owner/principal. The shareholders, therefore, will have to incur 'agency costs; costs that arise from the need of creating incentives that align the interests of the executive with those of the shareholder, and costs incurred by the necessity of monitoring executive conduct to prevent the abuse of owner interests. Some of the managers do not own a major stake in the bank and may not gain many rewards as compared to their corporate input as increasing the value of the bank or also absorb the cost in terms of loss. 


\section{Empirical review}

Srairi (2015) investigated the impact of the level of corporate governance disclosure on bank performance by constructing a corporate governance disclosure index (CGDI) for 27 Islamic banks operating in five Arab Gulf countries. Using content analysis on the banks' annual reports for 3 years (2011-2013), the composite index construction uses information on six important corporate governance mechanisms, namely board structure, risk management, transparency and disclosure, audit committee, Sharia supervisory board and investment account holders. The result indicates that the board audit committee increases the net income of Islamic banks. In a related study by Bahreini and Zain (2013) where they carried out a study on the impact of corporate governance characteristics specifically board of directors and audit committee on performance of the Malaysian banking sector. In this study, the sample includes one set of original data, financial information was obtained from the annual reports of thirty banks in Malaysia between the period 2005-2009 and data analyzed panel data model. Al-Baidhani (2014) investigated the effect of internal corporate governance mechanisms such as board structure, ownership structure, and audit function on bank financial performance in seven Arabian Peninsula countries. Regression analysis (OLS) is used to test the aforementioned effect. The results of this study reveal that there is a significant relationship between corporate governance and bank profitability. Danoshana and Ravivathani (2013) studied the impact of corporate governance on the performance of financial institutions in Sri Lanka. Twenty-five listed financial institutions were selected as the sample size for the sample period of 20082012. The data were collected by using secondary sources. According to the analysis, variables of corporate governance significantly impact on performance and board size and audit committee size have a positive impact on the firms' performance. However, meeting frequency has a negative impact on the firms' performance.

Naushaud and Malik (2015) ascertained the effect of corporate governance denoted by board size, duality, agency cost etc. on the performance of selected 24 GCC banks. The results indicate that smaller boards are more capable of monitoring the management closely in the GCC banking sector. The presence of block holders in the ownership structure of the GCC banks tends to have a positive effect on the performance of the banking sector. Zadollah and Mohsen (2015) examined the relationship between corporate governance and earnings management in banks listed on Tehran Stock Exchange using the variables ownership structure, board composition and block shareholding and multi-variate regression analysis method and concluded that corporate governance has no significant effect on profit management. In a related study by Elbannan and Elbannan (2014) carried out in Egypt, block holders have a negative correlation with Egyptian bank performance. The result buttress that concentration of ownership may lead to exploitation of majority ownership over minorities that result in weak performance.

Ogege and Boloupremo (2014) studied the relationship between board composition and financial performance of banks in Nigeria. By the application of multiple regression analysis, it was found that board composition also improves profitability, one-unit increase in the ratio of non-executive directors to total directors will increase profitability by the coefficient. Thereby, an increase in the number of non-executive directors sitting on the board, the better the financial performance. Akhalumeh, Ohiokha and Ohiokha (2011) conducted a study on board composition and corporate performance in Nigeria with the variables return on equity, outside directors, board composition and board size using a cross-sectional design. The result indicates that there is no significant relationship between board composition and performance. Fazel, Melati, Suresh and Ali (2016) examined the effect of board structure on banks financial 
performance by moderating firm size in Malaysia using regression models. Board size, Board independence, return on assets were the variables studied. The findings showed that determinants of board structure have a significant effect on performance. Kumar and Singh (2012) using ordinary least square regression analysis for market-based measure for board composition and bank size find a positive but insignificant effect on bank performance. Saladi (2006) examined the relationship between corporate board structure and performance of banks in Australia using cross-sectional analysis. Board evaluation, multiple directors and directors' remuneration are the variables studied. The findings of the study revealed that investors are prepared to pay a good premium for good governance. Dika, Dibra, Brahimi and Bezo (2013) studied the effect of corporate governance of the commercial banks in the United States. They considered the extent of monitoring on such banks, board composition and takeovers, risk and capital structure, as well as ownership. It was discovered that corporate governance will help reduce the social costs derived from bank failures and poor bank performance.

\section{Methodology}

The study made use of the ex-post facto research design. The motive behind the use of ex-post facto research design is that the data for the study has already been published by reputable institutions and is considered to be valid for the study. This study made use of banks that are publicly listed. The researcher carefully studied the data contained in the annual report of the banks that constitute the population of the study. The data used for this study were collected/derived from the published annual report of the banks that serve as the sample of the study. These banks must be banks that are listed within the period covered 2006-2018. This research adopted the model of Coleman and Nicholas-Biekpe (2006) with slight modifications. The original model is stated as follows:

$$
Y_{i, t}=\beta_{0}+\beta_{1} G_{i, t}+\beta_{2} B S E_{i, t}+\beta_{3} B D T_{i, t}+\varepsilon_{i, t}
$$

To determine the effect of different corporate governance variables on performance indicators, the above model is therefore modified to examine the effect of corporate governance and bank performance. These models are stated as follows:

$$
\begin{aligned}
\operatorname{LogNPM}_{t} & =a_{0}+a_{1} \operatorname{LogBDACt}+a_{2} \operatorname{LogFMS}_{t}+a_{3} \operatorname{LogFDS}_{t}+\varepsilon_{t}----1 \\
\operatorname{LogGRV}_{t} & =a_{0}+a_{1} \operatorname{LogBSH}_{t}+a_{2} \operatorname{LogFMS}_{t}+a_{3} \operatorname{LogFDS}_{t}+\varepsilon_{t}-----2 \\
\log _{\mathrm{LoI}} & =a_{0}+a_{1} \operatorname{LogBDC}_{t}+a_{2} \operatorname{LogFMS}_{t}+a_{3} \operatorname{LogFDS}_{t}+\varepsilon_{t}-----3
\end{aligned}
$$

\section{Cross-sectional relationship: Net profit margin and board audit committee}

From the fixed effect model, board audit committee and firm size have a positive relationship with the net profit margin. On the contrary, the debt structure of banks has a negative relationship with their net profit margin. Board audit committee has a positive coefficient indicating that if the ratio of independent auditors against auditors from the management of the banks is increased, the net profit margin would rise by $19.88 \%$. 


\section{Pooled OLS, Fixed Effect and Random Effect Regression}

Dependent Variable: Net Profit Margin (NPM)

\begin{tabular}{|c|c|c|c|c|c|c|}
\hline Variables & \multicolumn{2}{|c|}{ Pooled OLS } & \multicolumn{2}{|c|}{ Fixed Effect } & \multicolumn{2}{|c|}{ Random Effect } \\
\hline & Coefficient & Prob. & Coefficient & Prob. & Coefficient & Prob. \\
\hline $\mathrm{C}$ & 96.07851 & 0.2346 & 107.6718 & 0.1820 & 98.18690 & 0.2146 \\
\hline BDAC & 0.498179 & 0.7555 & 0.198793 & 0.9007 & 0.447035 & 0.7751 \\
\hline FMS & $6.14 \mathrm{E}-09$ & 0.0105 & 4.63E-09 & 0.0824 & 5.97E-09 & 0.0121 \\
\hline FDS & -1.304084 & 0.0000 & -1.244784 & 0.0000 & -1.296463 & 0.0000 \\
\hline R-squared & 0.416754 & & 0.478868 & & 0.414991 & \\
\hline Adjusted R-squared & 0.403295 & & 0.431880 & & 0.401491 & \\
\hline S.E. of regression & 22.24593 & & 21.70654 & & 22.07555 & \\
\hline Sum squared resid & 64334.57 & & 57483.20 & & 63352.88 & \\
\hline Log-likelihood & -603.7966 & & -596.2521 & & & \\
\hline F-statistic & 30.96355 & & 10.19142 & & 30.73963 & \\
\hline Prob(F-statistic) & 0.000000 & & 0.000000 & & 0.000000 & \\
\hline Durbin-Watson stat & 1.767539 & & 1.671384 & & 1.754820 & \\
\hline \multicolumn{7}{|c|}{ Hausman Specification Test } \\
\hline & \multirow{2}{*}{\multicolumn{2}{|c|}{$\begin{array}{c}\text { Chi-Sq. Statistic } \\
\text { Probability }\end{array}$}} & \multicolumn{2}{|c|}{7.462340} & & \\
\hline & & & 0.048500 & & & \\
\hline
\end{tabular}

\section{Growth of revenue and block shareholding}

The result of the Hausman test reveals that the random effect model estimation is the preferred to the fixed effect model as the p-value is insignificant 5\% level. The random effect estimation shows that block shareholding and firm size have a negative relationship with the growth of revenue while firm debt structure exhibit a positive relationship with the growth of revenue. The coefficient of the constant -54.39746 means that if block shareholding, firm size and firm debt structure are held constant then the growth of revenue would depreciate by a factor of 54.40. The block shareholding coefficient of -0.463250 indicates that a percentage increase in the current board size would result in $43.63 \%$ reduction in the growth of revenue of banks. The coefficient value of $-5.63 \mathrm{E}-10$ for firm's size insinuates that a unit decrease in the size of the firm would result in the decline of growth of revenue by a factor of 5.63 while a unit increase firm debt structure would result to a corresponding increase in growth of revenue of banks by $1.28 \%$.

The F-statistic of 1.907682 and p-value of 0.131518 indicates that the independent variables did not jointly and significantly explain the changes in banks revenue growth within the period covered by this study. The adjusted R-squared reveals that $2.00 \%$ changes in banks revenue were attributable to block shareholding, firm's size and debt structure. The Durbin Watson statistic of 2.0 shows that the model is free from the autocorrelation problem. In other words, return on assets, size of the board, firm's size and debt structure are not correlated. 
Pooled OLS, Fixed Effect and Random Effect Regression

Dependent Variable: Growth of Revenue (GRV)

\begin{tabular}{|c|c|c|c|c|c|c|}
\hline \multirow[t]{2}{*}{ Variables } & \multicolumn{2}{|c|}{ Pooled OLS } & \multicolumn{2}{|c|}{ Fixed Effect } & \multicolumn{2}{|c|}{ Random Effect } \\
\hline & Coefficient & Prob. & Coefficient & Prob. & Coefficient & Prob. \\
\hline $\mathrm{C}$ & -48.29974 & 0.5126 & -66.84665 & 0.4669 & -54.39746 & 0.4669 \\
\hline $\mathrm{BSH}$ & -0.557011 & 0.3213 & -0.284369 & 0.4251 & -0.463250 & 0.4251 \\
\hline FMS & $-3.18 \mathrm{E}-09$ & 0.7752 & 4.53E-09 & 0.9628 & $-5.63 E-10$ & 0.9628 \\
\hline FDS & 1.325890 & 0.0357 & 1.206809 & 0.0413 & 1.281305 & 0.0413 \\
\hline R-squared & 0.045642 & & 0.124522 & & 0.042167 & \\
\hline Adjusted R-squared & 0.023618 & & 0.045586 & & 0.020063 & \\
\hline S.E. of regression & 100.8596 & & 99.71855 & & 98.90413 & \\
\hline Sum squared resid & 1322447. & & 1213142. & & 2.064808 & \\
\hline Log-likelihood & -806.3471 & & -800.5670 & & & \\
\hline F-statistic & 2.072385 & & 1.577500 & & 1.907682 & \\
\hline Prob(F-statistic) & 0.107020 & & 0.113594 & & 0.131518 & \\
\hline Durbin-Watson stat & 2.065160 & & 2.020732 & & 2.064808 & \\
\hline \multicolumn{7}{|c|}{ Hausman Specification Test } \\
\hline & Chi- & & 04345 & & & \\
\hline & Statistic & & & & & \\
\hline & Probability & & 24400 & & & \\
\hline
\end{tabular}

\section{Growth in net income and board composition}

The fixed effect estimation entails that board composition and firm debt structure have a negative relationship with growth in net income while firm size has a positive relationship with growth in net income.

Pooled OLS, Fixed Effect and Random Effect Regression Dependent Variable: Growth in Net Income (GNI)

\begin{tabular}{|c|c|c|c|c|c|c|}
\hline Variables & Pooled C & $\mathbf{L S}$ & Fixed $\mathbf{F}$ & fect & Random & ffect \\
\hline & Coefficient & Prob. & Coefficient & Prob. & Coefficient & Prob. \\
\hline $\mathrm{C}$ & 69.31850 & 0.4047 & 55.01936 & 0.4900 & 62.53141 & 0.4355 \\
\hline $\mathrm{BDC}$ & -0.423863 & 0.5300 & -0.471577 & 0.4668 & -0.444640 & 0.4907 \\
\hline FMS & $-1.00 \mathrm{E}-10$ & 0.9950 & 8.76E-09 & 0.6193 & $3.28 \mathrm{E}-09$ & 0.8398 \\
\hline FDS & -0.597049 & 0.5196 & -0.502173 & 0.5788 & -0.543607 & 0.5420 \\
\hline R-squared & 0.006175 & & 0.153672 & & 0.006072 & \\
\hline Adjusted R-squared & -0.016760 & & 0.077364 & & -0.016865 & \\
\hline S.E. of regression & 150.3771 & & 143.2477 & & 145.3624 & \\
\hline Sum squared resid & 2939725. & & 2503428. & & 2746929 & \\
\hline Log-likelihood & -859.8689 & & -849.1050 & & & \\
\hline F-statistic & 0.269233 & & 2.013839 & & 0.264712 & \\
\hline Prob(F-statistic) & 0.847484 & & 0.032455 & & 0.850722 & \\
\hline Durbin-Watson stat & 2.301976 & & 2.242891 & & 2.279150 & \\
\hline \multicolumn{7}{|c|}{ Hausman Specification Test } \\
\hline \multicolumn{2}{|c|}{ Chi-Sq. Statistic } & \multicolumn{3}{|c|}{6.868201} & & \\
\hline \multicolumn{2}{|c|}{ Probability } & \multicolumn{2}{|c|}{0.046200} & & & \\
\hline
\end{tabular}

The board composition coefficient of -0.471577 implies that a unit increase in the ratio of executive to non-executive directors would lead to $47.16 \%$ decrease in growth in net income of banks. The coefficient value of 8.76E-09 for firm's size entails that a percentage increase in 
the firm size would result in net income of banks appreciation by a factor of 8.76 . On the other hand, a percentage increase in firm debt structure would decrease net income of banks by a factor of 50.22. From the F-statistic of 2.013839 and p-value of 0.032455 , the fluctuation in net incomes of banks was significantly accounted by board composition structure, firm's size and debt structure with the regard to the scope of this research. The adjusted $\mathrm{R}$-squared value of 0.077364 is an inference that it is only $7.74 \%$ variation in net incomes of banks that was significantly explained by board composition, firm's size and debt structure. The Durbin Watson statistic of 2.2 shows the absence of autocorrelation problem in the model.

Result of diagnostic test

Breusch-Pagan Heteroskedasticity Result

\begin{tabular}{ccc} 
Model & F- Statistic & P-value \\
1 & 8.644716 & 0.03440 \\
2 & 16.876088 & 0.00075 \\
3 & 23.806997 & 0.00000 \\
\hline
\end{tabular}

Source: Computer output data using Gretl Software

Ramsey RESET Test

\begin{tabular}{cccc} 
Model & T- Statistic & Df & P-value \\
1 & 0.631827 & 128 & 0.0333 \\
2 & 4.464246 & 128 & 0.0134 \\
3 & 7.580587 & 128 & 0.0008 \\
\hline
\end{tabular}

Source: Computer output data using Gretl Software

Normality of residual test

\begin{tabular}{|c|c|c|}
\hline Model & Chi-Square(2) & P-value \\
\hline 1 & 39.971 & 0.00000 \\
\hline 2 & 230.726 & 0.00000 \\
\hline 3 & 63.729 & 0.00000 \\
\hline
\end{tabular}

Source: Computer output data using E-views 10.0

Unit Root Test Result: ADF Test Result at Level: Intercept

\begin{tabular}{lllll}
\hline Variables & ADF Test Statistic & $\begin{array}{l}\text { Test Critical } \\
\text { Value at } 1 \%\end{array}$ & $\begin{array}{l}\text { Test Critical } \\
\text { Value at 5\% }\end{array}$ & Remark \\
NPM & $-2.072467(0.26)$ & -4.582648 & -3.320969 & Not Stationary \\
GRV & $-2.894737(0.08)$ & -4.582648 & -3.320969 & Not Stationary \\
GNI & $4.071413(0.02)^{* *}$ & -4.582648 & -3.320969 & Stationary \\
BDS & $-2.699957(0.11)$ & -4.582648 & -3.320969 & Not Stationary \\
BDAC & $-3.834058(0.02)^{* *}$ & -4.582648 & -3.320969 & Stationary \\
BSH & $-3.049695(0.07)$ & -4.803492 & -3.403313 & Not Stationary \\
BDC & $-1.913069(0.31)$ & -4.582648 & -3.320969 & Not Stationary \\
FMS & $-0.584547(0.82)$ & -4.582648 & -3.320969 & Not Stationary \\
FDS & $-1.369202(0.53)$ & -4.803492 & -3.403313 & Not Stationary \\
\hline
\end{tabular}

Source: Computer Output using E-view 10.0.

Net profit margin and board audit committee

The positive influence of board audit committee on the net profit margin of banks in Nigeria favours the notion that the purpose of the audit committee is to increase the truth worthiness of 
the financial reports by auditing of financial statements. Finding of Al-Baidhani (2014), Umar and Mutiu (2016) for the Arabian Peninsula and Nigeria respectively. It is also in agreement with Danoshana and Ravivathani (2013) who noted that directors and audit committees that are independent from management should improve the firms' reporting system and the quality of reported earnings because they are not subject to potential conflicts of interest that reduce their monitoring capacity. The coefficient of the Adjusted R-squared entails that $43.19 \%$ changes in net profit margin were attributable to the size of the audit committee, firm's size and debt structure. Invariably, the current composition of the audit committee of three members within the management and three from shareholders as stipulated by Central Bank of Nigeria corporate governance code for commercial banks in Nigeria has a positive effect on net profit margin.

\section{Revenue growth rate and block shareholding}

The negative relationship between block shareholding and growth of revenue is evidence that block shareholding does not increase the revenue growth rate of banks operating in Nigeria. This result is line with the studies of Al-Baidhani (2014) and Wepukhalu (2016). It also supports the perspective of the agency theory that block shareholders can dominate the executive and management structure of firms by filling key positions; such owner-managers are in a position to execute activities that benefit them but which may be detrimental to the interests of minority shareholders and the firm performance. The Adjusted R-squared showed that only $2.00 \%$ changes in banks revenue were attributable to block shareholding even when it was controlled by firm size and debt structure. Thus, blocking shareholding by any institution is incapable of enhancing the revenue growth rate of commercial banks in Nigeria.

\section{Growth in net income and board composition}

The OLS regression reveals board composition has a negative relationship with growth in net income. This result might be that non-executive director is not involved in the day to day affairs of the banks; this will undermine their ability to monitor and advise the board because of the lack of the information that they have which will reduce the non-executive director ability to apply their function efficiently. This supports the works Umar and Mutiu (2016) for Nigeria and Srairi (2015) for GCC countries. It is observed from the regression output that the proportion of independent directors to the total number of directors does not increase the banks' net income growth rate in Nigeria. This did not favour the agency theory postulation that a greater presence of non-executive directors in the board safeguard shareholders interest and improve the performance of banks in Nigeria. The Adjusted R-squared indicates that only $7.73 \%$ variation in growth in net income was accounted by the composition of the board in the presence of control variables-firm size and financial structure attributed to the banks. Thus, the composition of the board cannot be said to be a determinant of the net income growth rate of commercial banks in Nigeria.

\section{Granger causality for board audit committee and NPM}

The finding disclosed that the board audit committee does not granger cause a net profit margin of banks in Nigeria at a 5\% level of significance. Rather, it is the net profit margin that granger cause board audit committee. There is a unidirectional relationship between board audit committee and net profit margin, causality runs from net profit margin to the board audit committee. The composition of the board audit committee does not have any significant effect on net profit margin but the level of net profit margin exerts a significant effect on the board audit committee. 


\begin{tabular}{|lcccc|}
\hline \multicolumn{1}{|c}{ Null Hypothesis: } & Obs & F-Statistic & Prob. & Remarks \\
\hline BDAC does not Granger Cause & 105 & 0.02724 & 0.9731 & No Causality \\
NPM & & 14.9617 & 0.0000 & Causality \\
NPM does not Granger Cause & & & & \\
BDAC & & & & \\
\hline FMS does not Granger Cause & 103 & 2.48219 & 0.0888 & $\begin{array}{c}\text { No Causality } \\
\text { NPM }\end{array}$ \\
NPM does not Granger Cause & & 0.45773 & 0.6341 & No Causality \\
FMS & & & & \\
\hline FDS does not Granger Cause & 105 & 0.95007 & 0.3902 & No Causality \\
NPM & & 4.21761 & 0.0174 & Causality \\
NPM does not Granger Cause & & & & \\
FDS & & & & \\
\hline
\end{tabular}

Source: Computer analysis using E-views10.0

The results revealed that the board audit committee has no significant effect on the net profit margin of banks.

Granger causality for block shareholding and GRV

\begin{tabular}{|lcccc|}
\hline Null Hypothesis: & Obs & F-Statistic & Prob. & Remarks \\
\hline BSH does not Granger Cause & 105 & 1.43535 & 0.2429 & No Causality \\
GRV & & 0.49897 & 0.6087 & No Causality \\
GRV does not Granger Cause & & & & \\
BSH & & & & \\
\hline FMS does not Granger Cause & 103 & 0.55493 & 0.5759 & No Causality \\
GRV & & 0.05807 & 0.9436 & No Causality \\
GRV does not Granger Cause & & & & \\
FMS & & & & \\
\hline FDS does not Granger Cause & 105 & 0.60682 & 0.5471 & No Causality \\
GRV & & 0.16306 & 0.8498 & No Causality \\
GRV does not Granger Cause & & & & \\
FDS & & & & \\
\hline
\end{tabular}

Source: Computer analysis using E-views10.0.

The regression output indicates that block shareholding does not granger cause growth of revenue of banks in Nigeria. There is no unidirectional relationship between block shareholding and the growth of revenue. No causality running from block shareholding to growth of revenue at a significant level of 5\%. The regression output disclosed that block shareholding has a significant effect on the growth of revenue.

\section{Granger Causality for Board Composition and GNI}

The regression result shows that there is no causality between board composition and growth in net income of banks. Board composition does not granger cause growth in net income neither does growth in net income granger cause board composition at 5\% level of significance. The firm's size has no significant effect on growth in net income as it does not granger cause growth in net income at $5 \%$ significance level. 


\begin{tabular}{|lcccc|}
\hline \hline Null Hypothesis: & Obs & F-Statistic & Prob. & Remarks \\
\hline BC does not Granger Cause GNI & 105 & 0.17537 & 0.8394 & No Causality \\
GNI does not Granger Cause BC & & 0.05575 & 0.9458 & No Causality \\
\hline FMS does not Granger Cause & 103 & 0.19183 & 0.8258 & No Causality \\
GNI & & 0.23594 & 0.7903 & No Causality \\
GNI does not Granger Cause & & & & \\
FMS & & & & \\
\hline FDS does not Granger Cause GNI & 105 & 0.87051 & 0.4219 & No Causality \\
GNI does not Granger Cause FDS & & 0.59983 & 0.5509 & No Causality \\
\hline
\end{tabular}

Source: Computer analysis using E-views10.0.

\section{Summary of findings and recommendations}

Board audit committee has no significant effect on the net profit margin and is positively related to the net profit margin of banks. The net profit margin exerts significant influence on the board audit committee. Revenue growth is negatively related to block shareholding and is insignificantly affected by block shareholding. Only $2 \%$ of the change in the revenue growth rate was attributed to block shareholding and control variables. The composition of the board has no significant effect on growth in net income. The relationship between board composition and growth in net income is negative, only $7.74 \%$ of the variation in net income growth was as a result of changes in board composition, firm size and debt structure. The study concludes that a good corporate governance code should not be regarded as a threat to entrepreneurial drive and spirit. A system that combines enterprise with integrity will promote good corporate governance without stifling initiative and creativity.

The independence of the audit committee should be enhanced to having more ratios of outside directors compared to management directors in the audit committee. This is on the bases of the positive relationship between the audit committee and performance. The holding of block shares of the banks by individuals, institutional investors or agencies should be discouraged because it hurts performance. Block shareholding could induce the prioritisation of self-interest by block shareholders and the consequent expropriation of firm resources, resulting in decreased performance. Finally, the negative effect of board composition suggests the need for an optimum proportion of non-executive directors on the board for effective governance impacting the performance of the firm positively.

\section{References}

Abdulazeez, D. A., Ndibe, L. \& Mercy, A. M. (2016). Corporate Governance and Financial Performance of Listed Deposit Money Banks in Nigeria. Journal of Accounting and Marketing, 5(1):1-6.

Abobakr, M.G. (2017). Corporate governance and bank performance: Evidence from Egypt. Asian Economic and Financial Review. 7(12), 1326-1343

Adekunle, S.A.\&Aghedo, E.M. 2014.Corporate Governance and Financial Performance of Selected Quoted Companies in Nigeria European Journal of Business and Management 6(9):53-60 
Adigwe, P. K., Nwanna, I.O. \& John, E. I. (2016). Effect of Corporate governance mechanism on the financial performance of banks in Nigeria. Journal of Social Development. 5(2), 4150 .

Akhalumeh, P. Ohiokha, F. \&Ohiokha, G. (2011). Board Composition and Corporate Performance: An Analysis of Evidence from Nigeria. Research Journal of Finance \& Accounting. 2(4), 64-73.

Al-Baidhani, A. M. (2014). The Effects of Corporate Governance on Bank Performance: Evidence from the Arabian Peninsula. Retrieved from http://ssrn.com/abstract=2284814.

Bahreini, M. \&Zain, M. M. (2013). Impact of Corporate Governance on Performance of Banking Sector in Malaysia. Research Journal of Finance and Accounting. 4(19) 1-8.

Danoshana, M. S. \& Ravivathani, T. (2013). The Impact of the Corporate Governance on Firm Performance: A study on financial institutions in Sri Lanka. Merit Research Journal of Accounting, Auditing, Economics and Finance. 1(6):118-121.

Dharmastuti, C. \&Wahyudi, S. (2013). The Effectivity of Internal and External Corporate Governance Mechanism Towards Corporate Performance. Research Journal of Finance \& Accounting. 4(4); 1-9.

Dika, I., Dibra, R., Brahimi, F \&Bezo, Y. (2013). Corporate Governance in Banking System Research Journal of Finance and Accounting. 4(16): 18-22.

Egungwu, I. \&Egunwu, N.U. (2018). Effect of corporate governance on the asset quality of banks (Evidence from Nigeria). International Journal of Academic Research in Business and Social Sciences.8(12).1982-2002.

Elbannan, M. A. and Elbannan, M.A. (2014) Corporate Governance and Accounting Performance: A balanced scorecard. Accounting and Finance Research, 3(2).60-76.

Hajer, C. \& Anis, J. (2016). Analysis of the Impact of Governance on Bank Performance: Case of Commercial Banks. Journal of Knowl Economics, 872-895

Fanta, A. B., Kemai, K.S., Waka, Y.K. (2013). Corporate governance and impact on bank performance. Journal of Finance and Accounting. 1(1), 19-26.

Fazel, M., Melati, A. A., Suresh, R., \& Ali, A. (2016). The Effect of Board Structure On Banks Financial Performance by Moderating Firm Size. Mediterranean Journal of Social Sciences. 7(1): 258-259.

Kumar, N. \& Singh, J. P. (2012), Outside Directors, Corporate Governance and Firm Performance, Asian Journal of Finance and Accounting 4(2): 88- 98.

Love, I., Rachinsky, A., (2013). Corporate Governance, Ownership \& Bank Performance Emerging Market: Evidence from Russia and Ukraine. Journal of Corporate Finance. $4(6), 22-31$ 
Naushadi, M. \& Malik, S.A. (2015). Corporate Governance and Bank Performance: A Study of Selected Banks in GCC Region. Asian Social Science, Vol 11(9), 2015.

Marcinkowska, M. (2012). Corporate Governance in Banks: Problems and Remedies. Journal of Finance \& Banking 2(2): 243-267.

Muhammad, L.B. \& Fayrouk, M.A. (2014). Investigating the Impact of Internal Corporate Governance Mechanism on the Performance of Listed Deposit Money Banks in Nigeria. Journal of Banking and Finance.7(4):23-30

Ogege, S. \& Boloupremo, T. (2014). Corporate Governance and Financial Performance of Banks: Evidence From Nigeria. Hyperion Economic Journal 2(2): 39-45.

Onofrei, M., Firtescu, B. \&Terinte, P. (2018). Corporate governance influence on banking performance. An analysis on Romania and Bulgaria.

Onakoya, B.O., Ofoegu, I.D., \& Fasanya, O.I. (2012). Corporate Governance and Bank Performance: A pooled Study of Selected Banks in Nigeria. International Journal of Business And Management. Organization for Economic Coperation \& Development (2009).

Rahman, A. \& Islam, J. (2018). The impact of corporate governance on bank performance: Empirical evidence from Bangladesh. Global Journal of Management and Business Research. 18(8), 49-53.

Reskino, A.B. (2015). The Effect of Corporate Governance on Earnings Quality With Surplus Free Cash Flow as Moderating Variable. Research Journal of Finance \& Accounting, $6(4): 80-91$

Srairia, S. (2015). Corporate Governance Disclosure Practices and Performance of Islamic Banks in GCC Countries. Journal of Islamic Finance, 4(2):1-17.

Stout, A.L. (2012), The Problem of Corporate Purpose Issues in Governance Studies. A European Perspective Business \& society, March 2005 44:74-93.

Tijjani, M.S. \&Anifowose, M. (2013). Corporate Governance and Financial Performance of Listed Deposit Money Banks in Nigeria. Journal of Financial Economics, 5(7):43-51

Ugwuanyi, G.O. \&Amanze, P.G. (2014). Banking Sector Reform: An Approach to Restoring Public Confidence in the Nigerian Banking Industry. Research Journal of Finance and Accounting, 5(6):109-121.

Umar, M. S. \& Mutiu, A. T. (2016). A Firm-Level Analysis of Corporate Governance and Bank Performance in Nigeria. International Journal of Business and General Management, 5(3):7-20.

Uwuigbe, O. R. (2011). Corporate Governance and Financial Performance of Banks: A Study of Listed Banks in Nigeria. A Doctoral Thesis Submitted to the School of Postgraduate Studies, Covenant University, Ota, Ogun State. 
Wepukhulu, J. M. (2016). Relationship between Corporate Governance and Performance of Commercial Banks in Kenya. A thesis submitted to the Department of Business Administration Kenyatta University of Agriculture and Technology, Kenya.

Zadollah, F\& Mohsen, Z. K. (2015). The relationship between corporate governance and earnings management in banks listed on the Tehran Stock Exchange Research Journal of Finance and Accounting 6(13): 212-225. 